\title{
Extracellular enzyme activity in the Arctic Northeast Water polynya
}

\author{
Yves-Alain Vetter, Jody W. Deming \\ School of Oceanography WB-10, University of Washington, Seattle, Washington 98195, USA
}

\begin{abstract}
We studied extracellular enzyme activity (EEA) in samples of the water column and sediments of the Northeast Water polynya $\left(77^{\circ}\right.$ to $81^{\circ} \mathrm{N}, 6^{\circ}$ to $\left.17^{\circ} \mathrm{W}\right)$ during July-August 1992 in order to determine controls on bacterial hydrolytic activity and possible roles of EEA in the fates of particulate organic matter (POM) on an arctic continental shelf. Samples were taken by Niskin bottle, floating sediment trap and box corer from the USCGC 'Polar Sea' at stations throughout the polynya and icecovered surroundings. Fluorogenic substrate analogs were used to estimate potential maximal rates of peptidase, chitobiase and lipase EEA in time course experiments over incubation periods of 1.3 to $14 \mathrm{~h}$ at $-1,2,5,10$, and $16^{\circ} \mathrm{C}$. Increasing incubation temperature typically increased EEA, but psychrophilic rates (little to no increase upon warming) were detected in several samples, usually for peptidase activity. Rates adjusted to in situ temperature $\left(\mathrm{EEA}_{I S}\right)$ and normalized to bacterial abundance were compared to similarly determined rates reported previously for other (including temperate) environments and to each other. In general, EEA is rates in polynya waters were lower than in other pelagic environments, while rates in polynya sediments were comparable to those in other sediments. The whole polynya data set, which allows the first comparison between pelagic and benthic rates within a given environment, revealed that EEA IS rates (usually peptidase activity), whether normalized to bacterial abundance or to sample dry weight, were generally higher in pelagic samples, particularly in samples from sediment traps deployed in the subzero Polar Surface Water mass. Although relationships between $\mathrm{EEA}_{I S}$ and temperature or several other environmental parameters (measured by other researchers on the Polar Sea) could not be identified, chitobiase and lipase EEA IS did correlate positively, and peptidase activity negatively, with indicators of POM supply to the benthos (pigment concentrations). Observed differences in the effects of incubation temperature and environmental POM supply between enzymes may be explained by differences in location and regulation of peptidase and other EEA
\end{abstract}

KEY WORDS: Extracellular enzymes A Arctic polynya Psychrophilic bacteria $\cdot Q_{10}$ effects Marine sediments

\section{INTRODUCTION}

Organic material (OM) in seawater and marine sediments is composed primarily of high molecular weight compounds and particles unsuitable for direct utilization by bacteria (Thurman 1985). Hydrolysis of this material by extracellular enzymes (which include periplasmic and cell surface enzymes, as well as dissolved enzymes released from the cell) is necessary to generate smaller monomeric and oligomeric compounds that can by taken up by bacteria and used to support metabolism (Rogers 1961). Evidence for the dependency of bacterial growth on extracellular hydrolysis has been reported for some ocean regions (Hoppe et al. 1993), while extracellular enzyme activity (EEA) is generally recognized as the rate-limiting step in microbial degradation and utilization of organic polymers in waters and sediments (e.g. Hoppe 1991, Meyer-Reil 1991). In the pelagic ocean, the partitioning of particulate organic material (POM) between sinking and suspended pools appears to be mediated primarily by bacteria (Cho \& Azam 1988), specifically by extracellular hydrolysis at rates far exceeding growth requirements (Smith et al. 1992). In marine sediments, diagenesis of OM requires bacterial EEA (Deming \& Baross 1993). 
Despite the importance of extracellular hydrolysis to marine bacteria and OM cycling, patterns and controls of EEA in the ocean remain poorly understood. Relationships between enrichment with particulate and/or dissolved OM and EEA have been identified for several different enzymes in natural and artificial aquatic and sedimentary environments (e.g. Hoppe 1983, Rego et al. 1985, Chróst 1991, Meyer-Reil \& Köster 1992). However, correlations with organic parameters are often poor or variable (e.g. Reichardt 1986) and may sometimes be absent entirely (e.g. Mayer 1989). Evaluating the significance of organic enrichment for regulating EEA in natural environments is confounded by simultaneous induction (by refractory and/or polymeric OM) and catabolite (i.e. labile $\mathrm{OM}$ ) or end product repression of enzyme synthesis (Chróst 1991, Chróst \& Rai 1993 and references therein), as well as effects of animal feeding on OM composition and distribution (Köster et al. 1991). Temperature has also been identified as an important control on EEA. In situ temperature is sometimes the best (only) predictor of EEA rates in the environment (e.g. Mayer 1989), in keeping with the finding that activity rates measured for extracellular enzymes extracted from a variety of bacteria (including Arctic and temperate cultures) increase with incubation temperature (McDonald et al. 1963, Reichardt 1987, Margesin et al. 1991). On the other hand, decreased temperature dependence of enzymes isolated from psychrophilic as compared to mesophilic bacteria (McDonald et al. 1963, Margesin \& Schinner 1992) and increased production of extracellular enzymes by Antarctic bacteria at reduced temperature (Reichardt 1988) indicate thermal compensation mechanisms in some bacteria.

EEA was studied in both the water column and sediments of the Northeast Water (NEW) polynya $\left(77^{\circ}\right.$ to $81^{\circ} \mathrm{N}, 6^{\circ}$ to $17^{\circ} \mathrm{W}$ ) during July-August 1992 . This open body of water in an ice-covered region of continental shelf off Greenland communicates with the adjacent Greenland Basin via northern and southern cross-shelf extensions of a cirumferential trough system. A thick, cold $\left(-1.7\right.$ to $\left.0^{\circ} \mathrm{C}\right)$, relatively fresh layer of Polar Surface Water (PSW) carried by the East Greenland Current extends to the sea floor in the shallow central shelf region of the polynya and overlies warmer 10 to $1.1^{\circ} \mathrm{C}$ ), saltier bottom water derived primarily from Atlantic Intermediate Water (AIW) in deeper areas (Bourke et al. 1987; see NEWATER 1993 for bathymetry, hydrography and programmatic details). Changes in ice coverage, ice melt, dissolved nutrients and grazer populations produced spatial and temporal variability in production and benthic carbon delivery. Heterogeneity of physical, chemical and biological parameters within the polynya provided a natural laboratory in which to investigate the influence of various factors on EEA. The role of extracellular hydrolysis in regional OM cycling is of particular interest at this site because of the importance of high-latitude areas to carbon cycling in general (e.g. Broecker \& Peng 1989) and of polynyas and shelf seas in particular (Walsh et al. 1989). We wished to test the hypothesis that low temperature, by limiting EEA, favored storage of sedimented organic material in the polynya and export of suspended material from the polynya to adjacent waters. In exploring this hypothesis we developed new ideas about constraints on bacterial hydrolytic activity and the causes of psychrophilic EEA.

\section{MATERIALS AND METHODS}

Sample collection. Twelve samples of surficial sediment (SED) were collected by USNEL box core from sea floor overlain either by PSW or AIW-derived waters, 9 seawater samples (SW) by Niskin bottle from both water masses and 2 samples by short-term unpoisoned floating sediment trap (FST; Ducklow et al. 1982) deployed within the PSW water mass (Table 1). Sample temperature was determined by CTD at bottle trip (SW), bottom depth (SED) or by mean at deployment depth (FST). Although samples were taken throughout the study region, box coring was difficult in many of the shallower, rocky areas, thus limiting experimentation with sediments from colder sites. The logistics of deployment and retrieval restricted the number of FST samples that could be obtained.

Determining EEA. EEA in each sample was determined in duplicate for 3 classes of enzymes at a range of incubation temperatures using protocols from Hoppe (1983) and Mayer (1989). Some samples were analyzed for only 2 classes of enzyme. Added substrate was used at a concentration of $10 \mu \mathrm{M}$ for all experiments. The upper $\mathrm{cm}$ of sediment collected by box core was slurried with 9 parts sterile artificial seawater $(30 \%)$ to prepare SED samples in keeping with protocols for parallel amino acid utilization experiments (Deming unpubl.). SW and. FST samples were used without dilution. Every sample was divided into 3 subsamples, each amended with 1 of 3 enzyme substrate analogs, methylumbelliferyl glucosaminide (MUF-G). methylcoumarinyl leucine (MCA-L), or methylumbelliferyl palmitate (MUF-P). Each amended subsample was subdivided into 5 fractions, incubated at $-1,2,5$, 10 , and $16^{\circ} \mathrm{C}$. Each fraction was separated into four $12 \mathrm{ml}$ sterile plastic culture tubes for incubation and 1 subfraction (tube) was sacrificed (for each sample type, substrate and incubation temperature) for analysis at each time point. Samples, subsamples, fractions and subfractions were distributed by siphon while continu- 
Table 1. Samples analyzed for extracellular enzyme activity

\begin{tabular}{|c|c|c|c|c|}
\hline Stn no. & Lat. $N$, Long. $W$ & Sample ID & $\begin{array}{c}\text { In situ temp } \\
\left({ }^{\circ} \mathrm{C}\right)\end{array}$ & $\begin{array}{c}\text { Depth } \\
\text { (m) }\end{array}$ \\
\hline \multicolumn{5}{|c|}{ Sediment collected by box core (SC) } \\
\hline 25 & $80^{\circ} 27.34^{\prime}, 13^{\circ} 22.50^{\prime}$ & $\mathrm{SC} 3$ & 0.47 & 305 \\
\hline $25^{\prime}$ & $80^{\circ} 27.81^{\prime}, 13^{\circ} 22.16^{\prime}$ & SC 9 & 0.44 & 306 \\
\hline 42 & $80^{\circ} 02.46^{\prime}, 16^{\circ} 00.32^{\prime}$ & SC 29 & 0.55 & 437 \\
\hline 43 & $80^{\circ} 19.61^{\prime}, 9^{\circ} 34.36^{\prime}$ & $\mathrm{SC} 35$ & 0.44 & 312 \\
\hline 56 & $80^{\circ} 16.54^{\prime}, 8^{\circ} 40.83^{\prime}$ & $\mathrm{SC} 44$ & 0.44 & 288 \\
\hline 63 & $79^{\circ} 09.13^{\prime}, 13^{\circ} 50.43^{\prime}$ & SC 56 & -0.19 & 123 \\
\hline 64 & $79^{\circ} 00.46^{\prime}, 11^{\circ} 58.56^{\prime}$ & SC 61 & -0.06 & 216 \\
\hline 65 & $78^{\circ} 19.18^{\prime}, 16^{\circ} 46.28^{\prime}$ & SC 68 & 0.86 & 504 \\
\hline 72 & $77^{\circ} 09.00^{\prime}, 10^{\circ} 31.62^{\prime}$ & SC 72 & 0.81 & 474 \\
\hline 73 & $77^{\circ} 17.24^{\prime}, 10^{\circ} 03.80^{\prime}$ & SC 77 & 1.05 & 346 \\
\hline \multicolumn{5}{|c|}{ Water collected by Niskin bottle } \\
\hline 25 & $80^{\circ} 26.56^{\prime}, 13^{\circ} 19.89^{\prime}$ & CTD $34-394$ & 0.13 & 16 \\
\hline 25 & $80^{\circ} 26.72^{\prime}, 13^{\circ} 21.29^{\prime}$ & CTD $43-486$ & 0.55 & 293 \\
\hline 42 & $80^{\circ} 01.84^{\prime}, 16^{\circ} 00.45^{\prime}$ & CTD 62-699 & 0.56 & 387 \\
\hline 43 & $80^{\circ} 19.15^{\prime}, 9^{\circ} 41.13^{\prime}$ & CTD $73-785$ & 0.58 & 10 \\
\hline 43 & $80^{\circ} 17.02^{\prime}, 9^{\circ} 26.46^{\prime}$ & CTD 75.804 & -1.50 & 17 \\
\hline 49 & $80^{\circ} 44.53^{\prime}, 8^{\circ} 14.30^{\prime}$ & CTD $84-880$ & -1.48 & 50 \\
\hline 55 & $80^{\circ} 03.85^{\prime}, 9^{\circ} 19.80^{\prime}$ & CTD $91-965$ & -120 & 140 \\
\hline 55 & $80^{\circ} 03.85^{\prime}, 9^{\circ} 19.80^{\prime}$ & CTD $91-971$ & -1.68 & 50 \\
\hline 72 & $77^{\circ} 09.20^{\prime}, 10^{\circ} 30.25^{\prime}$ & CTD $117-1257$ & $\begin{array}{ll}7 & 1.37\end{array}$ & 250 \\
\hline 25 & $80^{\circ} 26.31^{\prime}, 13^{\circ} 26.02^{\prime a}$ & FST 1 & $-1.74^{b}$ & 50 \\
\hline 43 & $80^{\circ} 30.04^{\prime}, 13^{\circ} 24.21^{\prime}$ & FST 2 & -1.66 & 40 \\
\hline \multicolumn{5}{|c|}{ "Latitude and longitude at trap deployment } \\
\hline
\end{tabular}

samples, these were made with seawater. Because of problems of fluor adsorption and the natural fluorescence of sediment pore waters, SED standards and controls were extracted from splits of the same sediments used to measure EEA. $Q_{10}$-values (see below) were used to adjust EEA at the nearest incubation temperature to EEA at in situ temperature (EEA $\left.A_{i S}\right)$

Determining $\mathbf{Q}_{\mathbf{1 0}}$. The effect of temperature on EEA was determined by comparing rates measured at different incubation temperatures. For each sample and enzyme, an Arrhenius diagram was made by plotting the log of EEA against the inverse of temperature for all 5 incubation temperatures. The slope of the best-fit line through these 5 points was calculated to determine the effect of temperature on EEA. These slopes are reported here as $Q_{10}$, the factor by which EEA increases for a $10^{\circ} \mathrm{C}$ increase in temperature. $\mathrm{Q}_{10}$-values for amino acid utilization rates in sediments were determined in the same way for comparative purposes. $Q_{10}$ for EEA in the polynya were also compared with those available in the literature. Only values determined for whole environmental samples were considered (i.e. data determined for purified enzymes are excluded).

ously stirred with magnetic stir-bars to ensure an even distribution of material. Duplicate, independent samples were prepared for every incubation. Samples were not stirred during incubation. All steps involved in sample distribution and preparation (which required less than $10 \mathrm{~min}$ ) and analysis were accomplished in a refrigerated van set at $1^{\circ} \mathrm{C}$.

The substrate analogs are hydrolyzed by extracellular enzymes in the sample, either peptidase (MCA-L), lipase (MUF-P) or chitobiase (MUF-G), the activity of which is inferred to increase in parallel with chitinase activity (O'Brien \& Colwell 1987). The umbelliferone or coumarin derivative, fluorescent when free in solution but not when conjugated to companion molecules, is released during incubation. Sample subfractions were sacrificed, boiled for $60 \mathrm{~s}$ to stop EEA, buffered (borax buffer, pH 10), and (increasing) fluorescence measured with a Turner fluorometer equipped with a Wratten 7-60 excitation filter ( $360 \mathrm{~nm}$ center wavelength) and an Omega 441 BP11 (interference) emission filter. Fluorescence in whole subfractions was measured in SW and FST samples. SED samples were centrifuged 5 min in a bench top centrifuge and fluorescence measured in the supernates.

Standard curves and controls were used to convert the fluorescence increase rate to EEA. For SW and FST
Other parameters. Bacterial counts were made on all samples by epifluorescence microscopy according to Deming \& Colwell (1985) and J. C. Relexans, J. Deming, A. Dinet, J. F. Gaillard \& M. Sibuet (unpubl.). Amino acid utilization $\left({ }^{14} \mathrm{C}\right.$ incorporation and respiration) by sediment bacteria over a range of temperatures was determined for selected samples (Deming unpubl. work based on Deming 1993). Benthic (Ambrose \& Renaud 1994, based on Yentsch \& Menzel 1963) and pelagic (Wallace et al. 1993, Smith et al. 1994) pigment concentrations were determined fluorometrically. Sediment organic carbon and nitrogen contents were measured with a Control Equipment Corporation Model 440 elemental analyzer (Ambrose \& Renaud 1994). Total suspended particulates were measured by calibrated transmissometer (Smith et al. 1994, based on Gardner et al. 1993). Most hydrographic and chemical data have been published elsewhere (Wallace et al. 1993).

Comparisons of $\mathrm{EEA}_{I S}, \mathrm{Q}_{10}$, and relationships to other parameters. Normalizing EEA IS to bacterial abundance or sample dry weight allowed samples of all 3 types (SED, SW and FST) to be compared to each other and equally to other parameters. However, only SED and SW samples could be examined for relationships between $\mathrm{EEA}_{I S}$ and environmental parameters (other 
than temperature), since measurements of the other relevant parameters for FST samples were not made during trap deployment. Normalizing to bacterial abundance also allowed rates to be compared to similarly determined independent reports of $E E A_{I S}$ in the case of peptidase activity [available only for sediment (MeyerReil 1987, Mayer 1989) and seawater (Hoppe 1983) samples] and of chitobiase activity [available only for seawater (Hoppe 1983)]. Literature values were sometimes calculated from data presented graphically. Data suitable for extracting literature rates normalized to sample dry weight were not available. Only values determined for whole environmental samples were considered. $Q_{10}$-values (which are independent of the factor chosen to normalize EEA $A_{I S}$ ) for all samples were compared to each other and, in the case of SED samples, to the corresponding data calculated for amino acid uptake.

Several statistical methods were used to analyze data. Because heteroscedasticity of EEA is was confirmed in many cases by Bartlett's test, Kruskal-Wallis analysis of variance by ranks, a non-parametric analog of Tukey's test (Zar 1984), and the Mann-Whitney test were used for comparisons of EEA IS. Ranks of chitobiase and lipase EEA Is were summed and compared with ranks of peptidase activity for each sample by Spearman's rank correlation. (The use of ranks allowed rates of different magnitudes for chitobiase and lipase activity to be combined). Positive skewness indicated use of these same methods to analyze $Q_{10}$ data. Relationships between $\mathrm{EEA}_{I S}$ and other parameters were examined using Mood's non-parametric linear regression procedure (Tate \& Clelland 1957) and Spearman's rank correlation; these results were compared with conclusions drawn from principal components analysis (PCA). Parametric analogs of the regression and comparison tests were employed to confirm results and to permit estimates of power and probability to be determined for selected data.

\section{RESULTS}

\section{Effects of incubation temperature on EEA}

The greatest range and highest values of $Q_{10}$ for each type of enzyme activity were observed in SW samples (Fig. 1, Table 2). However, differences in mean or median $Q_{10}$-values between each sample type (SW, SED, FST) could not be detected for any of the activities (Table 2). We caution against the conclusion of equality of $Q_{10}$ for an enzyme activity across different sample types because the spread of the data makes differences difficult to detect. On the other hand, differences in central tendency of $Q_{10}$-values between different enzyme activities (as opposed to sample type)

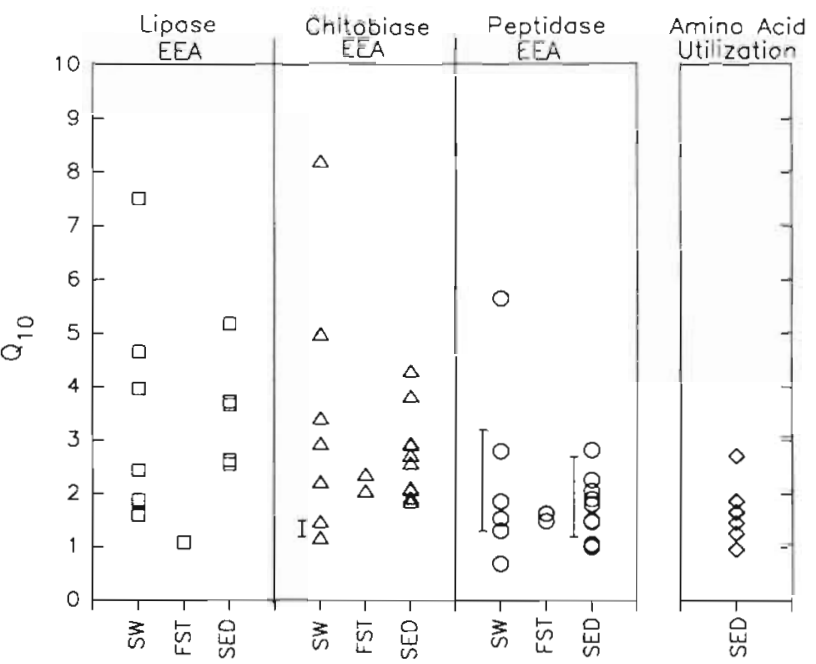

Fig. 1. $Q_{10}$ for the effect of temperature on extracellular enzyme activity (EEA; left 3 panels) and sediment amino acid utilization (right panel) rates. Lipase $(\square)$, chitobiase $(\Delta)$ and peptidase (O) rates are reported for the upper $\mathrm{cm}$ of sediments (SED), for seawater samples (SW) and for floating sediment trap samples (FST). Vertical bars for chitobiase $Q_{10}$ in $S W$ samples and peptidase $Q_{10}$ in SW and SED samples indicate the ranges of $Q_{10}$ reported by or calculated from works by other researchers in a variety of environments (McDonald et al. 1963, Weimer \& Morita 1974, Hollibaugh \& Azam 1983, Helmke \& Weyland 1986, Mayer 1989, Meyer-Reil \& Köster 1992 ). Only $Q_{10}$ determined for whole samples (not enzyme extracts) are reported

could be detected in SED and FST samples (Table 2). For each sample type, chitobiase $Q_{10}$-values were among the highest and peptidase $Q_{10}$ among the lowest. Although differences in central tendency of $Q_{10}$-values for different enzyme activities could not be detected in SW samples, highest values were calculated for chitobiase and lowest for peptidase, the same pattern observed in SED and FST samples.

$Q_{10}$-values $\leq 2$ were detected for 1 or more enzyme class in 15 of the 21 samples examined ( 7 SED, 6 SW and 2 FST samples). In the case of peptidase activity, the majority $(>70 \%)$ of experiments with a given sample type yielded $Q_{10} \leq 2 . Q_{10} \leq 2$ for chitobiase activity was detected less frequently and then only in SED and SW samples (20\% and $25 \%$, respectively). $Q_{10} \leq 2$ for lipase activity was detected only in SW and FST samples (33\% and $100 \%$, respectively). $Q_{10}$-values $\leq 1$ were detected for peptidase activity in 1 SED and 1 SW sample.

Few literature values of $Q_{10}$ for EEA in environmental samples were available for comparison, $Q_{10}$-values for peptidase activity in sediments of the NEW polynya corresponded closely to temperature characteristics (Arrhenius $\mu$ ) reported for peptidase activity of extracellular enzymes from cultures of Arctic sediment bacteria (McDonald et al. 1963). Chitinase activity measured in cultured Antarctic bacteria by Helmke \& 
Table 2. Comparisons of $Q_{10}$ for extracellular enzyme activity (EEA) and amino acid utilization. $M$, $S$ or $F$ : sample from sediment (mud), seawater or floating sediment trap, respectively. Subscripts C, L or P: chitobiase (MUF-G), lipase (MUF-P) or peptidase (MCA-L) activity, respectively. A: sample from an amino acid uptake experiment. Samples sharing a common underline are not significantly different from one another

\begin{tabular}{|c|c|c|c|c|}
\hline \multirow[t]{2}{*}{ Comparison $^{\circ}$} & \multicolumn{4}{|c|}{ Probability and significant differences ${ }^{b}$} \\
\hline & \multicolumn{2}{|c|}{ Parametric analysis } & \multicolumn{2}{|c|}{ Non-parametric analysis } \\
\hline \multicolumn{5}{|c|}{ Intercomparisons of $Q_{10}$ for $E E A$ : } \\
\hline Between environments & \multicolumn{4}{|c|}{ Not significant for any enzyme activity } \\
\hline \multicolumn{5}{|l|}{ Between substrates } \\
\hline Sediment samples & $p=0.001$ & $M_{p} M_{C} M_{L}$ & $p=0.003$ & $\mathrm{M}_{\mathrm{p}} \mathrm{M}_{\mathrm{C}} \mathrm{M}_{\mathrm{L}}$ \\
\hline Seawater samples & $p>0.1$ & Not significant & $p>0.1$ & Not significant \\
\hline FST samples & $\mathrm{p}=0.010$ & $\underline{F_{L} F_{p}} \underline{F_{C}}$ & $p>0.1$ & Not significant \\
\hline \multicolumn{5}{|l|}{ Pooled data } \\
\hline Environments, substrates & $\mathrm{p}>0.1$ & Not significant & $p>0.1$ & Not significant \\
\hline \multicolumn{5}{|c|}{ Comparisons of $Q_{10}$ for EEA to $Q_{10}$ for amino acid utilisation: } \\
\hline Sediment samples & $\mathrm{p}<0.001$ & $\underline{A M_{P}} \underline{M_{C} M_{L}}$ & $p=0.001$ & $\underline{A M_{P}} \underline{M_{C} M_{L}}$ \\
\hline
\end{tabular}

Weyland (1986) and protease activity measured by Reichardt (1988) clearly indicate psychrophily, but presentation of the data precludes comparison with results from this study. A comparison of EEA $Q_{10}$ with amino acid utilization $Q_{10}$ in polynya sediments (Fig. 1) revealed that values for the latter process were lower (more psychrophilic). Although central values for peptidase EEA and amino acid utilization were not significantly different, central values for sediment chitobiase and lipase $Q_{10}$ were significantly greater than those for sediment amino acid utilization (and peptidase EEA).

\section{EEA $_{\text {IS }}$ normalized to bacterial abundance}

The highest central (mean or median) EEA Is rates for chitobiase and lipase when normalized to bacterial abundance were measured in FST samples (Fig. 2, Table 3). Central values were lower (and indistinguishable from each other) in SW and SED samples. FST peptidase rates were equally high but indistinguishable from central values for peptidase rates in SW or SED samples (Fig. 2, Table 3). In fact, no significant differences between SW and SED samples were detected
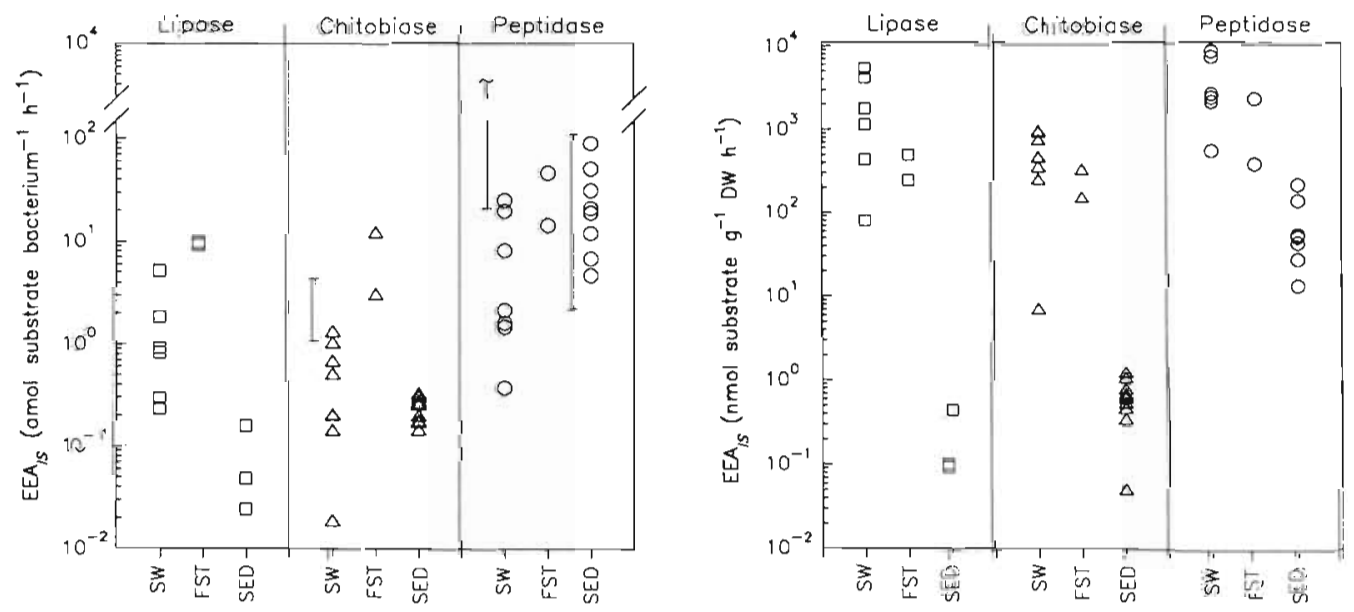

Fig. 2. Extracellular enzyme activity rates calculated for in situ temperature $\left(E_{E} A_{i S}\right)$. Left plot is EEA is normalized to bacterial density; right plot, to sample dry weight (note difference in units: amol vs nmol). Ranges of EEA is reported by or calculated from works by other researchers using similar techniques are indicated by vertical bars for chitobiase activitiy in SW samples and peptidase activity in SW and SED samples (Hoppe 1983, Meyer-Reil 1987, Mayer 1989). Comparable literature data were available only for rates normalized to bacterial abundance. Symbols as in Fig. 1 
for any enzyme activity when normalized to bacterial abundance (Table 3). Other features emerged from a consideration of rates normalized to bacterial abundance: (1) the range of $\mathrm{EEA}_{\mathrm{S}}$ for chitobiase in SED samples was narrower than for other enzyme activities or sample types (Fig. 1); (2) the highest EEA is in SW samples were all recorded at Stn 49 , the most northerly station occupied; and (3) SED samples taken from depths shallower than $300 \mathrm{~m}$, and therefore at the lowest in situ temperatures, yielded some of the highest chitobiase and lowest peptidase rates. A comparison of bacteria-normalized rates to similar values extracted from the literature revealed that SW chitobiase and peptidase rates in the polynya were generally lower than those measured in other pelagic environments, while SED peptidase rates were comparable to those measured in other benthic environments.

\section{EEA $_{\text {IS }}$ normalized to sample dry weight}

Slightly different patterns result from normalizing $\mathrm{EEA}_{\text {is }}$ to sample dry weight (Fig. 1), primarily due to increased bacterial abundance relative to weight of total particulate matter in seawater compared to the other, particle-rich sample types. Rates in FST samples were no longer the highest for each type - they overlapped instead with rates in SW samples (though significant differences in central tendency could not be detected with SED samples either; Table 3). Rates in SW samples were higher and significantly different in most cases from lower SED-values (Table 3). Normalizing to sample dry weight reveals increased potential for influence of EEA on material cycling in pelagic as compared to benthic environments. Regarding specific enzymes, peptidase $\mathrm{EEA}_{\text {IS }}$ rates exceeded chitobiase

Table 3. Comparisons of $\mathrm{EEA}_{I S}$ rates. $\mathrm{M}, \mathrm{S}$ or $\mathrm{F}$ : sample from sediment (mud), seawater or floating sediment trap, respectively Subscripts C, L or P: chitobiase (MUF-G), lipase (MUF-P) or peptidase (MCA-L) activity, respectively. Samples sharing a common underline are not significantly different from one another

\begin{tabular}{|c|c|c|c|c|}
\hline \multirow[t]{2}{*}{ Comparison $^{\text {d }}$} & \multicolumn{4}{|c|}{ Probability and significant differences ${ }^{b}$} \\
\hline & \multicolumn{2}{|r|}{ Parametric analysis } & \multicolumn{2}{|c|}{ Non-parametric analysis } \\
\hline \multirow{2}{*}{\multicolumn{5}{|c|}{ Rates normalized to bacterial abundances: }} \\
\hline & & & & \\
\hline Chitobiase & $\mathrm{p}<0.001$ & $M_{C} S_{C} F_{C}$ & $\mathrm{p}=0.062$ & Not significant \\
\hline Peptidase & $p>0.1$ & Not significant & $p>0.1$ & Not significant \\
\hline Lipase & $\mathrm{p}<0.001$ & $M_{\mathrm{L}} S_{\mathrm{L}} F_{\mathrm{L}}$ & $p=0.017$ & $\mathrm{M}_{\mathrm{L}} \mathrm{S}_{\mathrm{L}} \mathrm{F}_{\mathrm{L}}$ \\
\hline \multicolumn{5}{|l|}{ Between substrates } \\
\hline Sediment samples & $p=0.009$ & $\mathrm{M}_{\mathrm{L}} \mathrm{M}_{\mathrm{C}} \mathrm{M}_{\mathrm{P}}$ & $p<0.001$ & $M_{L} M_{C} M_{P}$ \\
\hline Seawater samples & $p=0.044$ & $\underline{\mathrm{S}_{\mathrm{C}} \mathrm{S}_{\mathrm{L}} \mathrm{S}_{\mathrm{P}}}$ & $p=0.011$ & $\mathrm{~S}_{\mathrm{C}} \mathrm{S}_{\mathrm{L}} \mathrm{S}_{\mathrm{P}}$ \\
\hline FST samples & $p>0.1$ & Not significant & $p>0.1$ & Not significant \\
\hline \multicolumn{5}{|l|}{ Pooled data } \\
\hline Environments, substrates & $\mathrm{p}=0.001$ & $M_{L} M_{C} S_{C} S_{L} F_{C} S_{p} F_{L} M_{p} F_{P}$ & $p<0.001$ & $M_{L} M_{C} S_{C} S_{L} F_{C} S_{P} F_{L} M_{P} F_{P}$ \\
\hline
\end{tabular}

Rates normalized to dry weight of sediment or total suspended particulates:

Between environments

$\begin{array}{lll}\text { Chitobiase } & p<0.001 & \frac{M_{C} F_{C} S_{r}}{M_{p} F_{p} S_{p}} \\ \text { Peptidase } & p=0.021 & \end{array}$

Lipase $\quad p>0.1 \quad$ Not significant

$\mathrm{p}=0.001 \quad \mathrm{M}_{C} F_{C} \mathrm{~S}_{\mathrm{C}}$
$\mathrm{p}=0.001$

$p>0.1 \quad$ Not significant

Between substrates

Sediment samples

$p=0.003 \quad M_{L} M_{C} M_{p}$

$\mathrm{p}<0.001 \quad \mathrm{M}_{\mathrm{L}} \mathrm{M}_{\mathrm{C}} \mathrm{M}_{\mathrm{P}}$

Seawater samples

$\mathrm{p}=0.035 \quad \mathrm{~S}_{\mathrm{L}} \mathrm{S}_{\mathrm{C}} \mathrm{S}_{\mathrm{P}}$

FST samples

$p>0.1$

Not significant

$p=0.010$

$\mathrm{S}_{\mathrm{L}} \mathrm{S}_{\mathrm{C}} \mathrm{S}_{\mathrm{P}}$

Pooled data

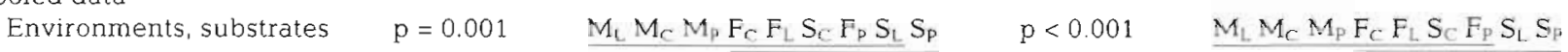

"p-values by ANOVA or the Kruskal-Wallis test. Multiple comparisons performed by the Tukey-Kramer test or a nonparametric analog (Zar 1984). ${ }^{\mathrm{b}}$ Scored at the $\alpha=0.05$ significance level 


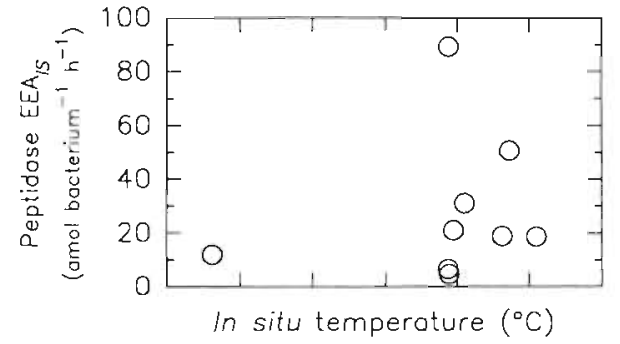

Fig. 3. Peptidase EEA IS $_{\text {is }}$ in sediments versus in situ temperature; plots of other enzyme activities in sediments and the water column were similar. These data have little power to detect a relationship between EEA is and temperature ( $1-\beta=0.06$ for this example) because the overall temperature range is small and rates from subzero and intermediate temperature sites are under represented or absent due to logistical difficulties encountered in sampling such sites under heavy ice

and lipase in both SW and SED samples, while no significant differences between enzyme activities could be detected in FST samples (Table 3). As with SED rates normalized to bacterial abundance, colder SED samples obtained above $300 \mathrm{~m}$ usually yielded the highest chitobiase and lowest peptidase rates. No weight-normalized rates were available in the literature for comparison.

\section{$\mathrm{EEA}_{\text {IS }}$ and environmental parameters}

The effects of environmental temperature on EEA $/ 5$ were studied directly by comparing EEA IS in SED and SW samples with in situ temperature. Results were inconclusive because the range of in situ temperatures represented in the samples was too narrow and sample sizes too small (e.g. for peptidase activity in Fig. 3). Statistical power was so low that any choice of slope would have fit the data (for the example in Fig. 3, the probability of correctly rejecting $H_{0}$ : no correlation between $\mathrm{EEA}_{\text {IS }}$ and in situ temperature, is less than 0.06).

EEA IS normalized to bacterial abundance and to sample dry weight for each enzyme for SED and SW samples was compared with sampling depth, in situ temperature, bacterial abundance, sediment bacterial amino acid utilization, carbon, nitrogen, chlorophyll and phaeopigment concentrations, and total (depthintegrated) chlorophyll and phaeopigment concentrations in the overlying water column. In SW samples, none of the environmental parameters correlated well with $\mathrm{EEA}_{I S}$, although highest rates were often measured in productive surface waters and lower rates in samples from greater depths. Because of limited sample size, statistical comparisons of
EEA rates for FST-collected material were not attempted

In contrast, several environmental parameters (pelagic and benthic) were predictive of EEA IS in SED samples. The total concentration of phaeopigments in the overlying water column was the best predictor, whether activity was normalized to bacterial abundance or to sediment dry weight (Fig. 4). Other predictive parameters included the total concentration of chlorophyll in the water column, which was predictive of chitobiase and peptidase activity, and the concentrations of carbon, chlorophyll and bacteria in the sediments, which were predictive of chitobiase activity (Table 4). Statistics obtained for relationships between $E A_{I S}$ and other characteristic parameters of SED samples should be viewed cautiously; several variables are not independent, and relationships between them are poorly known. Neither pelagic pigment, benthic pigment nor carbon concentration correlated well with sediment bacterial concentration, indicating that correlations of these same parameters with $\mathrm{EEA}_{I S}$ normalized to sediment dry weight were probably not incidental results of increases in sediment bacterial concentration.

The importance of pigment, carbon and bacterial concentrations for characterizing NEW polynya SED samples was also revealed by PCA (Table 5). The first principal component was loaded heavily by these environmental parameters and by EEA IS (especially dry weight-normalized chitobiase activity) and explained more than half the variance observed in the data. The second principal component, loaded primarily by depth and in situ temperature, explained less than $20 \%$ of the observed variance. EEA IS did not load heavily on the second principal component, consistent with our inability to detect an effect of in situ temperature (or depth) on enzyme activity.

Although pelagic phaeopigment concentration provided the best overall predictor of EEA is in polynya sediments, chitobiase and lipase activity correlated positively and peptidase activity correlated negatively (Fig. 4). The same pattern was observed in relationships between EEA $_{I S}$ and most other environmental parameters characterizing the polynya sediments. Even where statistical analysis failed to reveal a significant relationship between $\mathrm{EEA}_{I S}$ and a particular parameter, regression produced positive slopes for chitobiase and lipase activity and negative slopes for peptidase activity. This pattern was also reflected in the directions of the loadings of these enzyme activities in the first principal component identified by PCA (Table 5). Highest rates and a wider range of peptidase activity were measured consistently at the lowest concentrations of each environmental parameter, producing an envelope of peptidase EEA $\mathrm{A}_{\text {IS }}$ that decreased 


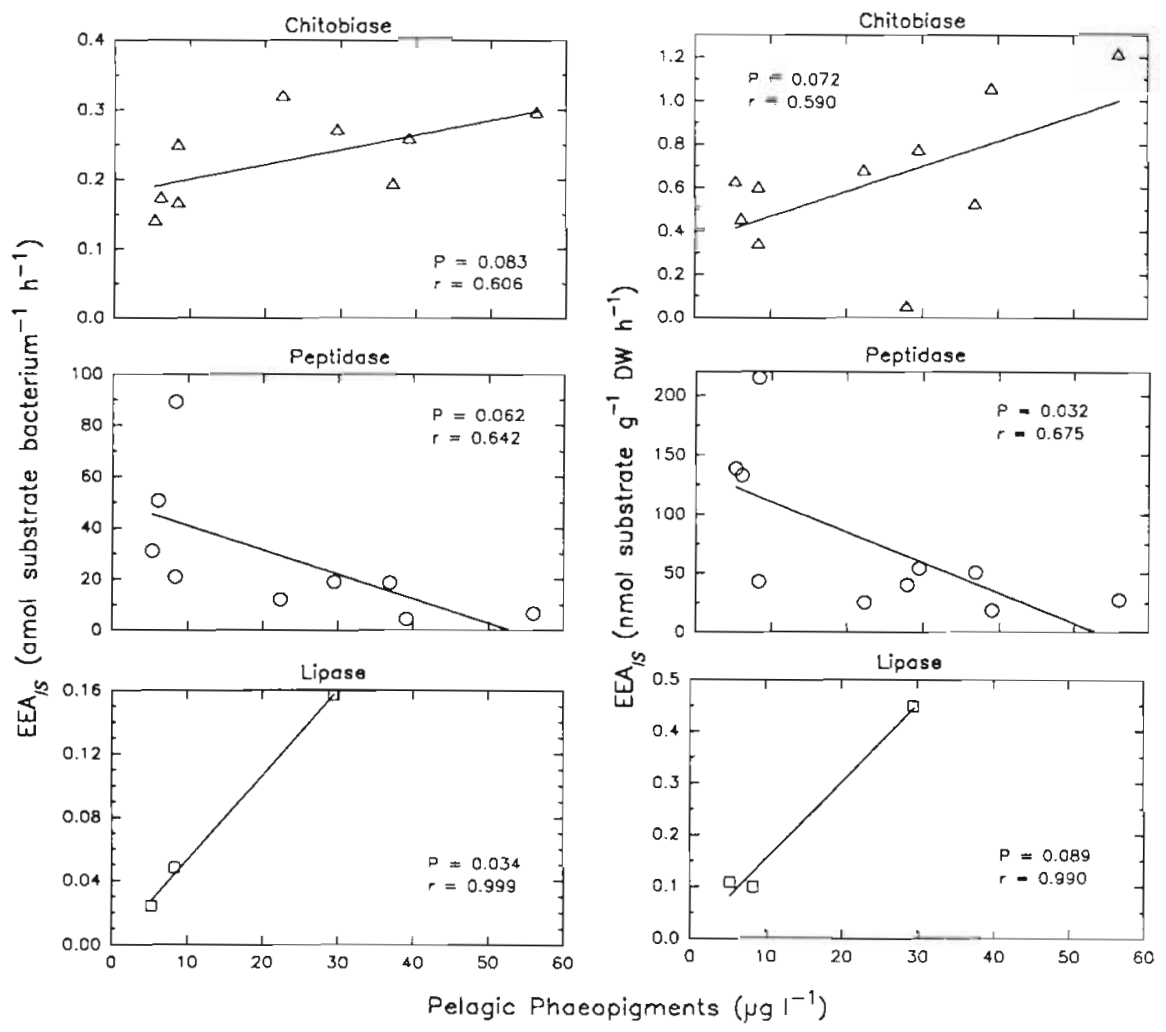

Fig. 4. EEA ${ }_{\text {IS }}$ in sediments versus pelagic phaeopigments concentrations. EEA $I S$ is normalized to bacterial abundance (left panels) and to sediment dry weight (right panels). Symbols as in Fig. 1 in width as the concentration of the environmental parameter increased. This effect (seen in Fig. 4) was observed also for environmental parameters that did not correlate significantly with peptidase $\mathrm{EEA}_{\text {IS }}$ normalized to bacterial abundance (e.g. sediment carbon, nitrogen, pigment and bacterial concentrations; data not shown).

The possibility of an inverse relationship between different enzyme activities in sediments was examined by testing for a correlation of peptidase with the other enzyme activities. $E_{\text {EAs }}$ per bacterium for peptidase was compared with chitobiase activity alone and with chitobiase plus lipase activity (lipase activity was not tested alone because of limited data). Marginally significant inverse relationships were identified in both cases (chitobiase plus lipase activity shown in Fig. 5).

Table 4. Comparisons of EEA rates in sediments to other environmental parameters. Temperature, depth, and sediment nitrogen are not reported because no significant correlations with sediment EEA were observed for these parameters

\begin{tabular}{|c|c|c|c|c|c|c|}
\hline Enzyme & $\begin{array}{l}\text { Bacteria } \\
\mathrm{g}^{-1} \mathrm{DW}\end{array}$ & $\begin{array}{l}\text { Sediment } \\
\text { carbon }\end{array}$ & $\begin{array}{c}\text { Sediment } \\
\text { phaeopigments }\end{array}$ & $\begin{array}{l}\text { Sediment } \\
\text { chlorophyll }\end{array}$ & $\begin{array}{c}\text { Pelagic } \\
\text { phaeopigments }\end{array}$ & $\begin{array}{c}\text { Pelagic } \\
\text { chlorophyll }\end{array}$ \\
\hline \multicolumn{7}{|c|}{ Comparisons with EEA normalized to bacterial abundance: } \\
\hline Chitobiase & $\begin{array}{c}\mathrm{p}=0.867^{\circ} \\
0.5<\mathrm{p}\end{array}$ & $\begin{array}{c}p=0.170 \\
0.1<p<0.2\end{array}$ & $\begin{array}{c}p=0.216 \\
0.2<p<0.5\end{array}$ & $\begin{aligned} p & =0.229 \\
0.2 & <p<0.5\end{aligned}$ & $\begin{array}{c}\mathrm{p}=0.083^{b} \\
0.05<\mathrm{p}<0.1\end{array}$ & $\begin{array}{c}p=0.122 \\
0.1<p<0.2\end{array}$ \\
\hline Peptidase & $\begin{array}{c}p=0.387 \\
0.5<p\end{array}$ & $\begin{array}{c}\mathrm{p}=0.177 \\
\mathbf{0 . 0 5}<\mathrm{p}<0.1\end{array}$ & $\begin{array}{c}p=0.275 \\
0.2<p<0.5\end{array}$ & $\begin{array}{c}p=0.241 \\
0.2<p<0.5\end{array}$ & $\begin{array}{c}p=0.062 \\
0.005<p<0.01\end{array}$ & $\begin{aligned} p & =0.065 \\
0.02 & <p<0.05\end{aligned}$ \\
\hline Lipase & $\begin{array}{c}p=0.891 \\
0.5<p\end{array}$ & $\begin{array}{c}p=0.293 \\
0.5<p\end{array}$ & $\begin{array}{c}p=0.832 \\
0.5<p\end{array}$ & $\begin{array}{c}p=0.834 \\
0.5<p\end{array}$ & $\begin{array}{c}\mathbf{p}=\mathbf{0 . 0 3 4} \\
0.5<p\end{array}$ & $\begin{array}{c}p=0.349 \\
0.5<p\end{array}$ \\
\hline \multicolumn{7}{|c|}{ Comparisons with EEA normalized to sediment dry weight: } \\
\hline Chitobiāse & $\begin{array}{c}\mathrm{p}=0.046 \\
0.05<\mathrm{p}<0.1\end{array}$ & $\begin{aligned} p & =0.014 \\
0.01 & <p<0.02\end{aligned}$ & $\begin{array}{c}p=0.139 \\
0.2<p<0.5\end{array}$ & $\begin{array}{c}\mathbf{p}=\mathbf{0 . 0 2 4} \\
0.5<p\end{array}$ & $\begin{array}{c}p=0.072 \\
0.1<p<0.2\end{array}$ & $\begin{array}{c}p=0.061 \\
0.05<p<0.1\end{array}$ \\
\hline Peptidase & $\begin{array}{c}\mathrm{p}=0.821 \\
0.5<\mathrm{p}\end{array}$ & $\begin{array}{c}p=0.263 \\
0.2<p<0.5\end{array}$ & $\begin{array}{c}p=0.188 \\
\mathbf{0 . 0 5}<\mathbf{p}<\mathbf{0 . 1}\end{array}$ & $\begin{aligned} p & =0.212 \\
0.02 & <p<0.05\end{aligned}$ & $\begin{aligned} \mathrm{p} & =0.032 \\
0.02 & <\mathrm{p}<0.05\end{aligned}$ & $\begin{array}{c}\mathbf{p}=\mathbf{0 . 0 7 5} \\
0.1<p<0.2\end{array}$ \\
\hline Lipase & $\begin{array}{c}p=0.768 \\
0.5<p\end{array}$ & $\begin{array}{c}p=0.170 \\
0.5<p\end{array}$ & $\begin{array}{c}p=0.709 \\
0.5<p\end{array}$ & $\begin{array}{l}p=0.711 \\
0.5<p\end{array}$ & $\begin{array}{c}\mathbf{p}=0.089 \\
0.5<p\end{array}$ & $\begin{array}{c}p=0.226 \\
0.5<p\end{array}$ \\
\hline \multicolumn{7}{|c|}{$\begin{array}{l}\text { 'Upper value of each pair is the } 2 \text {-tailed probability of the calculated regression line; bottom value; the 2-tailed probability of } \\
\text { Spearman's } x_{\mathrm{S}} \\
{ }^{\circ} \text { Bold type indicates } p<0.1\end{array}$} \\
\hline
\end{tabular}


Table 5. First 3 principal components in sediment data. Lipase EEA data were excluded from this analysis because measurements in sediments were available from only 3 stations

\begin{tabular}{|lccc|}
\hline \multirow{2}{*}{ Character } & \multicolumn{3}{c|}{ Component loadings } \\
& Component 1 & Component 2 & Component 3 \\
\hline Pelagic phaeopigments & 0.895 & -0.019 & -0.209 \\
Pelagic chlorophyll & 0.804 & 0.022 & -0.329 \\
Sediment phaeopigments & 0.831 & -0.036 & 0.456 \\
Sediment chlorophyll & 0.853 & -0.015 & 0.425 \\
Sediment carbon & 0.795 & 0.319 & -0.211 \\
Sediment nitrogen & 0.615 & 0.443 & -0.542 \\
Bacteria g ${ }^{-1}$ DW & 0.599 & 0.534 & 0.402 \\
Depth & -0.260 & 0.930 & -0.209 \\
In situ temperature & -0.126 & 0.870 & 0.038 \\
EEA normalized to bacterial abundance & & \\
Chitobiase & 0.615 & -0.534 & -0.184 \\
Peptidase & -0.708 & 0.124 & 0.355 \\
EEA normalized to sediment dry weight & & \\
$\quad$ Chitobiase & 0.939 & 0.067 & 0.160 \\
Peptidase & -0.684 & 0.289 & 0.421 \\
Percent of total variance & $50.8 \%$ & $18.7 \%$ & $12.6 \%$ \\
explained by component & & & \\
& & & \\
\hline
\end{tabular}

infusing a stirred or diluted sediment sample with dissolved artificial substrate may often lead to a higher enzyme-substrate encounter rate, and therefore higher hydrolysis rate, than can occur in situ between natural enzymes and substrates, both of which are frequently associated with the solid phase in the undisturbed matrix. We used added substrate at a concentration of $10 \mu \mathrm{M}$ to facilitate comparison with other studies; this concentration may sometimes be sub-saturating (Hoppe 1983). We use the term EEA $E_{1 S}$ for 'in situ' rates only to indicate that an adjustment to in situ temperature has been made.

Normalizing EEA rates to bacterial number also is problematic. First, while chitobiase activity may be restricted to bacteria, the contributions to measured peptidase and lipase rates by other organisms are unknown. Second, only a (variable) fraction of the bacteria counted in any sample will be active and contributing to EEA;

\section{DISCUSSION}

Although the use of fluorogenic substrates to assay enzyme activity in environmental samples is increasingly common, no standardized protocol exists, the concentration of natural substrates is unknown and the specificity of natural enzymes for artificial substrates is largely undetermined. Choices about the type and concentration of artificial substrate used will necessarily affect measured rates (Meyer-Reil 1986, Griffith \& Fletcher 1991) which may approximate the rate of in situ hydrolysis only rarely. For example,

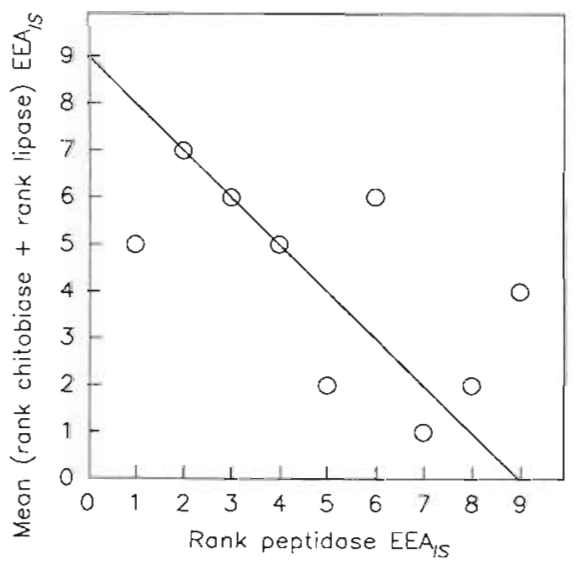

Fig. 5. Mean of ranked chitobiase and lipase EEA 15 versus peptidase EEA Is in sediments. Spearman's $I_{S}=0.6$, $0.05<p<0.1$. Diagonal line indicates relationship that would be expected if a common cell-surface area were allocated for peptidase and/or other enzyme activities differences between stations or sample types will affect bacteria-normalized EEA rates. The relative increase (compared to other sample types) in EEA by FST samples when normalized to bacterial number rather than sample dry weight may result from a relative abundance of active bacteria in FST samples.

Interpreting $Q_{10}$ data obtained with fluorogenic substrates is less perilous; provided diffusion is not limiting (likely for most protocols), experimental factors should influence EEA similarly at each incubation temperature, changing the height but not the slope of the lines used to calculate $Q_{10}$. $Q_{10}$-values recorded in the polynya bound the entire range of published measurements of temperature effects on EEA in environmental samples. One reason is that the complete data set acquired for the polynya more than doubles the number of such $Q_{10}$-values available in the literature. The unusually high $\mathrm{Q}_{10}$-values we obtained may have resulted from the range of water mass temperatures in the polynya and advection from adjacent regions. Some samples may have contained bacteria that were adapted to higher temperatures elsewhere, but suffered loss of activity when advected into colder polynya environments. Also, because $Q_{10}$ is essentially a ratio, small values in the denominator (i.e. $E E A \approx 0$ at $-1{ }^{\circ} \mathrm{C}$ ) rapidly inflate apparent temperature effects. The narrower range of $\mathrm{Q}_{10}$-values in polynya SED than in SW samples may have resulted, conversely, from a predominance of psychrophiles among benthic bacteria. The relative decrease in advection through sedimentary environments should favor establishment and dominance of psychrophiles among benthic as com- 
pared to pelagic microbial populations. This could also help explain why benthic but not pelagic EEA IS rates in the polynya equaled those in warmer regions.

Two processes critical to EEA are influenced by temperature at different rates: enzyme and substrate diffusion and hydrolysis after enzyme-substrate encounter. $\mathrm{A} \mathrm{Q}_{10}$ for diffusional transport of about 1.4 has been predicted for dissolved substrates in seawater at the range of temperatures investigated in this study (Jumars et al 1993), whereas a $Q_{10}$ of 2 is typical for enzymatic hydrolytic reaction rates (Atkins 1982). Microbial populations adapted to prevailing nutrient concentrations should manifest joint diffusion- and reaction-rate limitation (Jumars et al. 1993), resulting in an observed $Q_{10}$ for EEA between 1.4 and 2.0. However, if we assume that the use of saturating concentrations of added substrate abated diffusion-rate limitation of EEA in our experiments and that incubation times were too short for significant bacterial adaptation via growth (there was no evidence of significant growth in the samples), then reaction-rate limitation is left to determine EEA rates.

The psychrophilic (herein defined as $Q_{10}<2$ ) and extremely psychrophilic $\left(Q_{10} \leq 1.4\right)$ EEA measured in this study are difficult to explain in terms of single enzyme reactions. Enzymes with temperature optima below $0^{\circ} \mathrm{C}$ might manifest very low $Q_{10}$, but such enzymes have not been identified. Mesophilic temperature optima are characteristic of the marine extracellular enzymes that have been studied, including some from Antarctic sediments (Reichardt 1987). We suggest a more likely explanation, especially for extremely psychrophilic EEA, is hydrolysis by enzyme systems subject to benefits and constraints conferred by (obligately) psychrophilic growth. The teleology of psychrophily is poorly understood, but cell membranes adapted to very low temperatures rapidly lose structure necessary for metabolism upon warming. If psychrophilic EEA required a concerted effort (e.g. of substrate encounter, hydrolysis and transport) by a system of spatially and temporally coordinated proteins (e.g. cell-surface-, periplasmic- and plasmamembrane proteins), effects of warming on membrane fluidity could slow substrate hydrolysis by disturbing relative orientations of component proteins. Consistent with this explanation is lower $Q_{10}$ measured for protease (gelatinase) activity by whole cells (probably psychrophilic for growth) than observed in partially purified enzyme from the same organism (Weimer \& Morita 1974). This reasoning also predicts that other processes mediated by membrane-bound protein and enzyme systems will manifest psychrophilic $Q_{10}$. In fact, psychrophilic, including extremely psychrophilic, $Q_{10}$-values were often measured for the whole-cell process of amino acid utilization (incorporation and respiration) in this study. Production of psychrophilic enzyme systems may offer cold-adapted bacteria an alternative to increased enzyme production, a strategy proposed by Reichardt (1987) to explain field results, and observed by Margesin \& Schinner (1992) for protease at low temperatures in psychrotolerant (previously known as psychrotrophic) laboratory cultures. It would be useful to know if the psychrotolerant strategy of increasing enzyme production levels is also adopted by psychrophilic bacteria.

A parallel question is why warming should increase proteolysis less rapidly than other enzyme activities, as it did in this work and in other studies using cultured bacteria (Kim 1991, Reichardt 1988). Such results can be explained by invoking a membrane-associated, psychrophilic hydrolytic system that affects protease but not chitobiase activity. This follows the suggestion of Hoppe (1983) that proteolysis more than other enzyme activities is associated specifically with active bacteria. For this study, it is consistent not only with the $Q_{10}$ observations but also with the opposite relationships of peptidase and other enzyme activities with environmental parameters (see below).

EEA rs rates measured in NEW polynya SED samples suggest that enzyme-dependent transformations of POM within polynya sediments could proceed at rates similar to those measured in other more temperate environments. The potential for long residence times of POM in polynya sediments, as hypothesized earlier (NEWATER 1993), may not be realized. In contrast, $\mathrm{EEA}_{I S}$ rates measured in SW samples may indicate retarded dissolution of pelagic POM in the polynya relative to other pelagic environments, with consequent implications for vertical export of fresh phytodetritus to polynya sediments or lateral export to adjacent environments.

In situ temperature had previously been found to be the best predictor of protease EEA IS in sediment samples from a seasonably variable temperate environment (Mayer 1989). An effect of in situ temperature could not be detected in this study despite moderate to high $Q_{10}$ for many of the samples collected. However, other environmental parameters, all reflecting inputs of organic matter to the sea floor, were predictive of $\mathrm{EEA}_{\text {is }}$ in SED samples

Chitobiase and especially lipase have been studied infrequently for correlation with organic enrichment, but a positive relationship of chitobiase activity with increasing eutrophication in water samples (Hoppe 1983) and an increase in sediment chitobiase activity following phytoplankton sedimentation (Reichardt 1986) have been reported. A negative relationship of protease EEA IS with organic enrichment has been observed frequently (e.g. Hoppe 1983, 1991, Reichardt 1986) but not always (cf. Mayer 1989). We suggest that 
the opposite relationships represented by these studies and observed in ours can be explained by constraints on bacterial use of extracellular enzymes and by nitrogen regimes. During periods of low nutrient input bacteria may maximize the expression of extracellular peptidases in order to obtain all available organic nitrogen. At other times, organic enrichment and particularly catabolite repression by amino acids in fresh detritus (Fontigny et al. 1987 and citations therein) may inhibit protease activity and permit expression of a more diverse suite of extracellular enzymes, producing opposite trends of peptidase with chitobiase and lipase EEA IS. We hypothesize that there is a common bottleneck on total bacterial extracellular enzyme production or use, requiring trade-offs between different hydrolytic activities to optimize enzyme foraging under different environmental conditions. This would be in addition to rate adjustments of specific enzyme activities designed to maximize the net return of hydrolysate to the cell. One bottleneck might be limited cell-surface and periplasmic space available for expression of cell-held extracellular enzymes (Jumars et al. 1993). An inverse relationship of protease $\mathrm{EEA}_{\text {IS }}$ with other enzyme activities (Fig. 5) would ensue as a consequence. This comparison suffers from a lack of data on the diverse suite of extracellular enzymes undoubtedly present in the samples studied and on the extent to which specific enzymes remain active apart from the living cell.

Different cell associations, lifetimes and other characteristics of extracellular enzymes complicate interpretation of enzyme-enzyme and enzyme-environment relationships. However, the following scenario is consistent with all of our results: microbial populations in this arctic environment respond quickly to organic inputs, limiting production of proteases which may lose activity rapidly upon substrate exhaustion or release from the cell; enzymes acting on more refractory and presumably widespread substrates (e.g. chitin) respond to changes in mean substrate levels rather than sporadic inputs, and may remain active apart from the cell. In fact, sediment carbon concentration, the best correlate of chitobiase $\mathrm{EEA}_{I S}$, does represent a longer-term average rate of organic material input to the sea floor than does pelagic pigment concentration, the best correlate of protease $\mathrm{EEA}_{15}$. Further, the correlation is with chitobiase activity normalized to sediment dry weight, not to bacterial abundance, consistent with significant cell-free, perhaps dissolved, chitobiase activity.

In summary, extracellular enzymes appear to manifest diverse environmental adaptations and processes of operation and regulation, with important consequences possible for microbial ecology and regional material disposition. On the mesoscale, we found no evidence that EEA $A_{I S}$ in NEW polynya sediments functions any differently in material cycling than in more temperate regions; in pelagic samples, EEA Is may be slowed in the polynya relative to more temperate environments, thus favoring the export of relatively unhydrolyzed POC. On the microscale, disparate locations of extracellular enzyme systems and activity can explain temperature and substrate effects observed in this study. Research with controlled systems is necessary to advance from speculation to well-defined alternative models.

Acknowledgements. This research was supported by NSF grant OPP9113960 with additional support from a NSF PYl grant to J.W.D. and an ONR University Research Initiative award to the University of Washington. We thank Shelly Carpenter for collecting bacterial samples, Jan Gaylord for endlessly counting the bacteria, Will Ambrose and Paul Renaud for sediment samples and sediment characterizations, Walker Smith for pelagic pigment data, Gil Rowe for floating sediment trap samples, and Ian Walsh for total suspended particulate material data. We also thank the U.S. Coast Guard officers and crew of the 'Polar Sea' for their outstanding help during NEWP'92.

\section{LITERATURE CITED}

Ambrose, W. G., Renaud, P. E. (1994). Benthic response to water column productivity patterns: evidence for benthicpelagic coupling in the Northeast Water polynya. J. geophys. Res. (in press)

Atkins, P. W. (1982). Physical chemistry, 2nd edn. W. H. Freeman \& Co., San Francisco

Bourke, R. H., Newton, R. G., Paquette, R. G., Tunnicliffe, D. (1987). Circulation and water masses of the East Greenland Shelf. J. geophys. Res. 92: 6729-6740

Broecker, W. S., Peng, T.-H. (1989). The cause of the glacial to interglacial atmospheric $\mathrm{CO}_{2}$ change: a polar alkalinity hypothesis. Global biogeochem. Cycles 3: 215-239

Cho, B. C., Azam, F. (1988). Major role of bacteria in biogeochemical fluxes in the ocean's interior. Nature 332: $441-443$

Chróst, R. J. (1991). Environmental control of the synthesis and activity of aquatic microbial ectoenzymes. In: Chróst, R. J. (ed.) Microbial enzymes in aquatic environments. Springer-Verlag, New York, p. 84-95

Chróst, R. J., Rai, H. (1993). Ectoenzyme activity and bacterial secondary production in nutrient-impoverished and nutrient-enriched mesocosms. Microb. Ecol. 25: 131-150

Deming, J. W. (1993). ${ }^{14} \mathrm{C}$ tracer method for measuring microbial activity in deep-sea sediments. In: Kemp, P. F., Sherr, B. F., Sherr, E. B., Cole, J. J. (eds.) Aquatic microbial ecology. CRC Press, Boca Raton, p. 405-414

Deming, J. W., Baross, J. A. (1993). The early diagenesis of organic matter: bacterial activity. In: Engel, M. H., Macko, S. A. (eds.) Organic geochemistry, Vol. 6, Topics in geobiology. Plenum Press, New York, p. 119-144

Deming, J. W., Colwell, R. R. (1985), Observations of barophilic microbial activity in samples of sediment and intercepted particulates from the Demerara Abyssal Plain. Appl. environ. Microbiol. 50(4): 1002-1006

Ducklow, H. W., Kirchman, D. L., Rowe, G. T. (1982). Production and vertical flux of attached bacteria in the Hudson River plume of the New York Bight as studied with floating 
sediment traps. Appl. environ. Microbiol. 43(4): 769-776

Fontigny, A., Billen, G., Vives-Rego, J. (1987). Some kinetic characteristics of exoproteolytic activity in coastal seawater. Estuar. coast. Shelf Sci. 25: 127-133

Gardner, W. D., Walsh, I. W., Richardson, M. J. (1993). Biophysical forcing of particle production and distribution during a spring bloom in the North Atlantic. Deep Sea Res 40(2): $171-195$

Griffith, P. C., Fletcher, M. (1991). Hydrolysis of protein and model dipeptide substrates by attached and nonattached marine Pseudomonas sp. strain NCIMB 2021. Appl. environ. Microbiol. 57(8): 2186-2191

Helmke, E., Weyland, H. (1986). Effect of hydrostatic pressure and temperature on the activity and synthesis of chitobiases of Antarctic Ocean bacteria. Mar. Biol. 91: 1-7

Hollibaugh, J. T, Azam, F. (1983). Microbial degradation of dissolved proteins in seawater. Limnol. Oceanogr. 28(6): $1104-1116$

Hoppe, H.-G. (1983). Significance of exoenzymatic activities in the ecology of brackish water: measurements by means of methylumbelliferyl-substrates. Mar. Ecol. Prog. Ser. 11: $299-308$

Hoppe, H.-G. (1991). Microbial extracellular enzyme activity a new key parameter in aquatic ecology. In: Chróst, R. J (ed.) Microbial enzymes in aquatic environments. SpringerVerlag, New York, p. 60-83

Hoppe, H.-G., Ducklow, H., Karrasch, B. (1993). Evidence for dependency of bacterial growth on enzyme hydrolysis of particulate organic matter in the mesopelagic ocean. Mar Ecol. Prog. Ser. 93: 277-283

Jumars, P. A., Deming, J. W., Hill, P. S., Karp-Boss, L., Yager P. L., Dade, W. B. (1993). Physical constraints on marine osmotrophy in an optimal foraging context. Mar. microb Food Webs 7: 121-159

Kim, S.-J. (1991). Bacterial number, heterotrophy and extracellular enzyme activity in the Bransfield Strait, Antarctica. Kieler Meeresforsch., Sonderh. 8: 205-212

Köster, M., Jensen, P., Meyer-Reil, L.-A. (1991). Hydrolytic activities of organisms and biogenic structures in deepsea sediments. In: Chróst, R. J. (ed.) Microbial enzymes in aquatic environments. Springer-Verlag, New York p. $298-310$

Margesin, R., Palma, N., Schinner, F. (1991). Proteases of psychrotrophic bacteria from glaciers. J. basic Microbiol 31(5): $377-383$

Margesin, R., Schinner, F. (1992). Extracellular protease production by psychrotrophic bacteria from glaciers. Int Biodeter. Biodeg. 29: 177-189

Mayer, L. M. (1989). Extracellular proteolytic activity in sediments of an intertidal mudflat. Limnol. Oceanogr. $34(6)$ 973-981

McDonald, I. J., Quadling, C., Chambers, A. K. (1963). Proteolytic activity of some cold-tolerant bacteria from Arctic sediments. Can. J. Microbiol. 9: 303-315

Meyer-Reil, L.-A. (1986). Measurement of hydrolytic activity and incorporation of dissolved organic substrates by microorganisms in marine sediments. Mar. Ecol. Prog. Ser. 31: $143-149$

Meyer-Reil, L.-A. (1987). Seasonal and spatial distribution of extracellular enzyme activities and microbial incorporation of dissolved organic substrates in marine sediments. Appl. environ. Microbiol. 53(8): 1748-1755

Meyer-Reil, L.-A. (1991). Ecological aspects of enzyme activity in marine sediments. In: Chróst, R. J. (ed.) Microbial enzymes in aquatic environments. Springer-Verlag. New York, p. $84-95$
Meyer-Reil, L.-A., Köster, M. (1992). Microbial life in pelagic sediments: the impact of environmental parameters on enzyme degradation of organic material. Mar. Ecol. Prog Ser. 81: $65-72$

NEWATER Steering Committee and Principal Investigators (1993). Northeast Water Polynya: Polar Sea cruise results EOS 74(16): 185, 195-196

O'Brien, M., Colwell, R. R. (1987). A rapid test for chitobiase activity that uses 4-methylumbelliferyl- $N$-acetyl- $\beta$-Dglucosamiride. Appl. environ. Microbiol. 53(7): 1718-1720

Rego, J. V., Billen, G., Fontigny, A., Somville, M. (1985). Free and attached proteolytic activity in water environments Mar. Ecol. Prog. Ser. 21: 245-249

Reichardt, W. (1986). Enzyme potential for decomposition of detrital biopolymers in sediments from Kiel Bay. Ophelia 26: $369-384$

Reichardt, W. (1987). Differential temperature effects on the efficiency of carbon pathways in Antarctic marine benthos. Mar. Ecol. Prog. Ser. 40: 127-135

Reichardt, W. (1988). Impact of the Antarctic benthic fauna on the enrichment of biopolymer degrading psychrophilic bacteria. Microb. Ecol. 15: 311-321

Rogers, H. J. (1961). The dissimilation of high molecular weight substances. In: Gunsalus, I. C., Stanier, R. Y. (eds.) The bacteria, Vol. 2, Metabolism. Academic Press, New York, p. 257-318

Smith, A. J., Minhas, T., Greenman, J., Embry, G. (1993). The distribution and properties of some hydrolytic enzymes from Porphyromonas gingivalis W50. Microbios 73: 185-197

Smith, D. C., Simon, M., Alldredge, A. L., Azam, F. (1992). Intense hydrolytic activity on marine aggregates and implications for rapid particle dissolution. Nature 359(6391): $139-142$

Smith, W. O. Jr, Walsh, I. D., Booth, B. C., Deming, J. W. (1994). Particulate matter and phytoplankton and bacterial biomass distributions in the Northeast Water polynya during summer 1992. J. geophys. Res. (in press)

Tate, M. W., Clelland, R. C. (1957). Nonparametric and shortcut statistics. Interstate Printers and Publishers, Danville, IL

Thurman, E. M. (1985). Organic geochemistry of natural waters. Martinus Nijhoff/Dr. W. Junk Publishers, Dordrecht.

Wallace, D. W. R., Hopkins, T S., Behrens, W. J., Kinder, C., Smith, W. O., Walsh, I. D. (1993). Collaborative research on the Northeast Water Polynya: hydrographic data report. Brookhaven National Laboratory, informal report. Upton, NY

Walsh, J. J., McRoy, C. P., Coachman, L. K., Goering, J. J., Nihoul, J. J., Whitledge, T. E., Blackburn, T H., Parker, P. L., Wirick, C. D., Shuert, P. G., Grebmeier, J. M., Springer, A. M., Tripp, R. D. Hansell, R. D., Djenidi, S., Deleersnijder, E., Henriksen, K., Lund, B. A., Andersen, P., Muller-Karger, F E., Dean, K. (1989). Carbon and nitrogen cycling within the Bering/Chuckchi Seas: source regions for organic matter effecting AOU demands of the Arctic Ocean. Prog. Oceanogr. 22: 277-359

Weimer, M. S., Morita, R. Y (1974). Temperature and hydrostatic pressure effects on gelatinase activity of a Vibrosp. and partially purified gelatinase. Z. allg. Mikrobiol 14(8): $719-725$

Yentsch, C. S., Menzel, D. W. (1963). A method for determination of phytoplankton chlorophyll and phaeophytin by fluorescence. Deep Sea Res. 10: 221-231

Zar, J. H. (1984). Biostatistical analysis. Prentice-Hall, Englewood Cliffs, NJ

Manuscript first received February 2, 1994

Revised version accepted: June 28, 1994 